\title{
IMPACT OF GENERATIVE LEARNING MODEL ON ACADEMIC SELF CONCEPT AND ACHIEVEMENT OF SECONDARY SCHOOL STUDENTS IN CHEMISTRY IN ONITSHA EDUCATION ZONE, ANAMBRA STATE, NIGERIA
}

\author{
George Patience Chinasa \\ Department of Science Education \\ Nnamdi Azikiwe University Awka \\ Mail: gernest770@gmail.com \\ Obikezie Maxwell Chukwunazo \\ Department of Science Education \\ Nnamdi Azikiwe University, Awka \\ Mail: cm.obikezie@unizik.ng \\ Abumchukwu Adanna Angela \\ Department of Science Education \\ Nnamdi Azikiwe University Awka \\ Mail: aa.abumchukwu@unizik.edu.ng
}

\begin{abstract}
The study investigated the impact of generative learning model (GLM) on academic selfconcept and achievement of secondary school students in Chemistry in Onitsha Education Zone, Nigeria. A quasi-experimental design was used involving a sample of 98 students, 67 males and 31 females from Onitsha education zone. The instruments known as chemistry self concept scale (CSCS) and chemistry achievement test (CAT) were used for data collection. The instruments were validated by three experts one from educational psychology and two from science education department all from Nnamdi Azikiwe University Awka-with reliability coefficient of 0.87 and 0.81 respectively were used for data collection. Four research questions and four hypotheses guided the study. Mean and standard deviation were used to answer research questions while analysis of Covalence (ANCOVA) was used to test the hypotheses at 0.05 level of significance. The results revealed that academic self concept of experimental group (GLM) improved more than control group, also GLM enhance achievement more than conventional method in teaching chemistry. Finding implies there is need for chemistry teachers to use GLM in teaching chemistry. Recommendations were made on how chemistry teachers, educational and institutional bodies should adopt the use of GLM to improve teaching and performance of students in chemistry.
\end{abstract}

Keywords: Generative Learning Model (GLM), Academic Self-Concept and Secondary School Students 


\section{Introduction}

Science has penetrated every branch of modern life. It is the noise of machine, car, mills and factories which awakens us every day in the morning. The food we eat, the clothes we wear, the book and paper we read, all have one thing or the other to do with the application of science. It was in recognition of the importance of science that Nigeria Government has continued to make serious effort towards providing her citizens with qualitative and quantitative science education programmes. In addition, looking at the modernization that takes place every day, the world work force requires people who could have acquired the necessary attitude and skill of science and technology. That is why Nzewi (2011) stated that, science and technological education are regarded as a vehicle for economic and social development in a country and the acceleration and sustainable development depend on the quality of scientists produced from science education. This implies that our nation's advancement in science depends to a large extent on its strong science education programmes.

Science education is the field of study which is concerned with sharing science contents and processes with individuals not traditionally considered part of the scientific community, thereby producing a scientific literate society (Offiah \& Igboegwu, 2010). Science education can be seen as a process of teaching and training especially in school to improve one's knowledge about one's environment and develop one's skill for systematic inquiry. It is important to note that science education and its application in technology are one of the most powerful instruments which can enable all members of the society to face the dynamic nature of science and modernization of today. It is also useful to understand that science education has branches which chemistry is part of it.

Chemistry is one of the branches of science that studies the properties, composition, and structures of matter together with the associated changes as well as how such changes impact on the welfare of man and the society (Ojokuku, 2010). Chemistry has made tremendous contributions in the world; it has helped man to understand the complexity of his body, the environment, benefit and hazard of this world. It has been increasingly used in providing solution to problems such as health, agriculture, food, shelter, and manufacturing. There is scarcely a single area of our daily lives that is not affected by chemistry. However, it is disheartening to note that chemistry students' academic achievement in the subject in senior secondary school certificate examination has remained consistently poor. This is supported by WAEC Chief Examiner's report (2014). According to the report, the students' weaknesses among others are poor knowledge of the concept of "chemical bonding" (electronic configuration, oxidation state, IUPAC nomenclature). This poor achievement has generated concern for the researchers to carry out this study.

Also, it seems there is disparity in the academic achievement of male and female students in chemistry. One wonders if student's academic self perception, confidence and effort (academic self concept) are considered in the conventional method employed by the teacher. The researchers have decided to employ a constructivist teaching model to see if students' achievement could be enhanced in teaching and learning of chemical bonding. This stem from the fact that constructivist methods are students centered and may consider students' academic self concept hence, improved their achievement. Thus, there is a need to employ strategy, which can influence and improve students' academic self concept and enhance the teaching and learning of chemical bonding and chemistry in general for effective teaching. The poor achievement of students in chemistry has been attributed to some students' factor 
such as; student sex role stereotyping, lack of interest and negative attitude towards chemistry and teacher related factor such as poor teacher preparedness and application of inefficient teaching methods (Chukwu, 2013). In Nigeria, efforts are being made by researchers, government and non-governmental organizations to diagnose the problems associated with teaching and learning of chemistry in order to proffer solution that lead to better achievement. However, the WAEC chief examiners (2014) comments indicate that achievement in chemistry at secondary school remains poor. Could it be that teachers' method or strategy of teaching is not effective to improve students' achievement?

Teaching strategies are the techniques, methods and styles that a teacher can adopt to meet the various learning objectives. Teaching strategies include manner of presentation, the way of arranging conditions, grouping students, guiding activities and providing information to aid learning. Teaching strategies are central to the teacher's goal and strive to enrich the learning environment in which the learner is engaged. The learning environment is the total physical and mental world to which the students is exposed at a particular time, and the enrichment of the environment implies making the learning experience of the physical and mental world more conducive for the students. In addition, looking at today's age (computer age), students need to be taught with innovative teaching strategies. This is to enable them think critically, explore their environment, acquired the necessary attitude and skill to become future scientist. Therefore teachers of today need innovative teaching strategy in order to improve the academic achievement of secondary school student in chemistry, since is the starting point of students for future carrier in the field of science.

Academic achievement may refer to a person's strong performance in a give academic arena. It can also be seen as sign of refined intellect which can help students in all areas of their lives. Academic achievement is important because it prepares students for future careers and those looking forward to enter academia need strong academic achievement. Also, students academic achievement need to improve in chemistry by focusing students variables such as academic self concept which is likely to give necessary solution to the problem of poor achievement.

Self concept can be referred as a cognitive descriptive component of one's self, and an important construct in psychology and education (Joyce \& Shirley, 2007). The earlier proponent of the self concept theory was Cal Rogers, 1947. Cal Roger's as a self enhancement theorist held that, the self is the central ingredient in human personality and personal adjustment. Joyce and Shirley added that self-concept is a multidimensional construct, having one general facet and several specific facets, one of which is academic selfconcept. Academic self-concept is a person's perception of self with respect to achievement in school and students self confidence, effort and self perception are components of one's self concept in a particular subject area (Majere, 2013). From the present researchers view, academic self concept is the cognitive, affective and psychomotive description of oneself in academic subject. It involves students' self perception, scholastic competence and skills in chemistry as a subject. According to Shavelson model in Sara, Nielsen and Ellen (2015), academic self concept is characterized by two elements; First, academic self-concept reflects descriptive (e.g., I like chemistry) as well as evaluative (e.g. I am good at chemistry) aspects of self-perception. Second, self-perceptions associated with academic self-concept tend to focus on scholastic competence, rather than attitudes. There seems to be disparity between the academic achievement of male and female students in chemistry. 
Gender may determine the academic perception of one self and the achievement in particular subject area. Georgian (2000) states that males' and females' perceptions of mathematics self efficacy and achievement is significantly different, suggesting that this difference in perception relates to girls' relatively lower mathematics performance and lower participation rates in mathematics related careers. Oloyede (2010) investigated gender difference in chemistry self concept and reveal finding revealed some gender differences in the self concept of students in the subject. Thus, it seems that gender stereotyping could be a militating factor to academic achievement in Nigeria Education setting. It is therefore important to investigate the effect of Generative Learning Model instructional strategy on male and female students' academic self concept and achievement in chemistry.

Effective teaching involves classroom teaching behavior/interaction between the teacher, the student, the subject matter and combination of these three dimensions (Akuezilo, 2009). To achieve effectiveness, in teaching and learning of science in general and chemistry in particular, teachers need to adopt some teaching model in the classroom. One of such models could be Generative Learning Model (GLM) instructional strategy.

Generative Learning Model (GLM) is a cognitive model of human learning with understanding that was developed by Wittrock, in 1974. It is a constructivist teaching strategy and instructional model that focused on cognitive processes that the students used to comprehend concept. GLM focuses on considering the students previous learning experience and understanding so that the learner can actively generate meaningful relationships between the prior knowledge and new information (Grabowski, 2007). The model provides students' opportunity for active participation in the learning process allows for group and individualized form of learning and empowers learners with ability to express their personal views through its phases. This is unlike the conventional methods, which have no direction or phases, and the teacher talks, writes, and in fact do everything in the classroom. The GLM phases direct both teacher and students in learning environment. There are several versions of generative learning model as proposed by many researchers such as Osbourne and Wittrock (1981), Boyan (1988), Lawson (1988), Abraham (1989) and Bybee, Buchwald, Crissman, Heel Kuerbis, Matsumoto and Nerney (1990). This study focuses on Bybee et al (1999) model. It is a teaching strategy with five instructional phase namely; engagement, exploration, explanation, elaboration and evaluation. The theory involves four key concepts that instructional designers can involve (all four of them or just one) depends on the needs of the learner and the learning materials involved. They are: recall, integration, organizer and elaboration.

Recall; this occurs when the learner accesses information stored in his long term memory. Integration; involves the learner integrating new information with knowledge already collected and stored. Organization; it involves learner linking knowledge they have already collected to new concepts in an effective way. Elaboration; involves the encouragement of the learner to connect and add new concepts to information that they have already collected, by analyzing the ideas. Teacher's role knows how and when to facilitate the learners' construction of relationship making the learner and teacher or instructor partners in the learning process is their priorities. Teacher has the collaborative task of guiding and facilitating the students' activity. The teacher identifies the students by gathering the students conceptual, preconceptions about their learning the topic. Identify Preconceptions about their role as a learner, prior knowledge relating to the topic and Meta cognitive abilities. It encourages learners to become fully immersed in learning, so that they can develop new strategies on how to solve problems or scenarios. It involves teacher allowing the struggling 
students to interact with more capable ones, who continue to mediate transactions for the benefit of all.

This theory has been one of the bases on which GLM is built upon. Since GLM of Bybee et al (1999) emphasizes on engagement and exploration through which students identified prior knowledge and links it to concept to be learned. Therefore it is necessary to investigate the impact of generative learning model of Bybee et al (1999) on students' academic self concept and achievement in chemistry. The study of self concept and school achievement by Bauer (2005), it was found that the relationship between self concept and school achievement was very specific. For him academic-self concept relates to how well we do in school or how well we learn. Marsh and Byrne (2003) considered it as an important component of students educational well being because it linked to both students motivation to succeed in school as well as their academic performance. According to Okonkwo, (2012), the structure of academic self- concept seem to include a global dimension functioning and specific domain which bear a stronger relation to individuals sense of competence, effort and confidence in schools or academic work such as chemistry, physics or mathematics. She stated further that, the domains-specific academic self-concept have important implication for individuals over all academic functioning. According to Marsh, general self concept and non academic aspect of self concept are not related to academic works but general academic achievements measure were found to relate positively to general academic self concept and are highly related to success in that content area. The perceptual psychologists postulated that all people create their own reality through in their perceptions of what they believe to be real and that a person's behaviour is contingent on how an individual perceives and interprets his/her experience (Opara, 2012). Thus from the perspective of the perceptual psychology it is clear that to understand an individual's behaviour, we need to know how that individual perceives and interprets his/her experiences in academic achievement.

Also Liu and Wang, (2005) studied students academic achievement and suggest that achievement is a psychological indicator of educational adjustment such as school engagement, and self-control. According to Wilkins (2014) academic self concept and academic achievements measures were found related to as positively to general concepts and are highly related to success in that content area. She further says that many students are not confident about their chemistry ability to solve problem. A poor self effort, interest towards the discipline is thought to plague learner at every level of schooling. According to Bauer, (2010), chemistry achievement is closely related to self-concept and interest towards chemistry concept. Self concept means self construction is one's cognitive and effective representation of one's own identity. Self concept is a collection of beliefs about one self (Marsh, 1990) element such as academic performance/achievement, gender roles. Features such as personality, skills and abilities, hobbies, physical characteristics, are assessed and applied to self schemas, which are ideas of oneself in a particular dimension.

Research agree on the importance of one's self concept, which influences people's behavior and cognition and emotional outcomes in study of academic achievement. Carl Rogers \& Maslow establish the notion of self concept as learned that is not present at birth. Also research suggested that to raise academic self concept parent and teacher need to provide children with specific strategies that focus on their particular skills or abilities. Trautwein, Ulrich, Herbent, Nagu, \& Gabriel (2009) state that learning opportunities should be conducted in groups (both mixed ability and like ability) that down play social comparison, as too much of either type of group can have adverse effect on children's academic self concept and the way they view themselves in relation to their peers. Therefore, there is need 
to investigate the impact of GLM instructional strategy on academic self concept achievement of student taught chemistry in secondary school.

\section{Purpose of the Study}

The purpose of the study was to investigate the effect of Generative Learning Model (GLM) instructional strategy on students' academic self concept and achievement in chemistry. Specifically, the study sought to investigate the:

1. Differences that exist between the mean self concept scores of students taught chemistry with GLM instructional strategy and those taught with conventional method.

2. Differences that exist between the mean achievement scores of students taught chemistry with GLM instructional strategy and those taught with conventional method.

3. Differences that exist between the mean self concept scores of male and female students taught chemistry with GLM instructional strategy.

4. Differences that exist between the mean achievement scores of male and female students taught chemistry with GLM.

\section{Research Questions}

The study provided answers to the under stated questions

1. What are the differences in the pretest and posttest mean self concept scores of students taught chemistry with GLM instructional strategy and those taught with conventional method?

2. What are the differences in the pretest and posttest mean achievement scores of students taught chemistry with GLM and those taught with conventional method?

3. What are the differences in the pretest and posttest mean achievement scores of male and female students taught chemistry with GLM instructional strategy?

4. What are the differences in the pretest and posttest mean self concept scores of male and female taught chemistry with GLM?

\section{Hypotheses}

The following null hypotheses were tested in the study at 0.05 level of significance

1. There is no significant difference in the mean achievement scores of students taught chemistry with GLM instructional strategy and those taught with conventional method.

2. There is no significant difference in the mean self concept scores of students taught chemistry with GLM in chemistry and those taught with conventional method.

3. There is no significant difference in the mean achievement scores of male and female students taught chemistry with GLM.

4. There is no significant difference in the mean academic self concept scores of male and female students taught chemistry with GLM.

\section{Methodology}

The study adopted a quasi - experimental research design, specifically; a non-equivalent control group design. It used a quasi experimental research design because participants' subject cannot be randomly assigned to experimental and control groups (Nworgu, 2008). 
Two intact classes were used in the study; one for experimental group and the other for control group. It is the study of effect of the systematic manipulation of one independent variable (GLM instructional strategy) on two dependent variables (students' academic self concept and achievement in chemistry). The study is summarized thus:

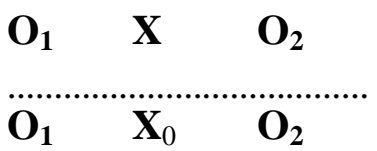

Where $\mathrm{O}_{1} \mathrm{X}$, and $\mathrm{O}_{2}$ represent experimental group, pre-test, treatment, and Post-test respectively for experimental group and $\mathrm{O}_{1}, \mathrm{X}_{\mathrm{o}} \mathrm{O}_{2}$, represents control group, pre-test, no experimental treatment and post-test respectively for control group. The dotted line represents' non equivalent group.

The study was carried out in Onitsha Education Zone of Anambra State. The zone has three Local Government Areas (LGAs) which consist of Onitsha North, Onitsha South and Ogbaru. The study was conducted in secondary school at Onitsha North and Onitsha South LGAs which have 16 and 9 schools respectively. The choice of these LGAs is that they have large number of student communities and completely urban. The towns around these LGAs are; Inland town, G.R.A., Nkpor, Fegge, and Woliwo. The people mostly live in cluster habitat. These LGAs is surrounded by big markets which make most of their population traders. Moreover, they have the same economical, political and cultural experiences and these provide equivalent grounds for any research work in the LGAs. To obtain this sample, the government owned secondary school in Onitsha education zone was stratified into two education zones which comprised Onitsha North and Onitsha South. Purposive sampling technique was employed to pick all the co- educational schools in the 2 LGAs. Then two schools that do not differ significantly were chosen through simple random sampling (balloting with replacement) as an experimental and control groups centers. Because, gender is one of the variables in the research, to ensure that both male and female that have similar background, experience and environmental exposure, were chosen purposive sampling was employed. Specifically, 50 students were used in experimental group and 48 students in control group. A total of $98 \mathrm{SS} 1$ students' constitute the sample for the study of 67 males and 31 females.

\section{Instruments}

The instruments used for data collection were chemistry self concept scale (CSCS) adapted by the researchers from the academic self concept inventory of Shavelson model in Joyce and Shirly (2007) and Chemistry Achievement Test (CAT) since the research involved two measuring instruments. Ten questions derived from the inventory were modified then ten new questions were constructed making the CSCS question to be 20. It was used in measuring perceived Chemistry academic self concept of the students. A four point rating scale with the response options of Strongly Agreed $(\mathrm{SA})=4$, Agree $(\mathrm{A})=3$, Disagree (D), $=2$ and Strongly Disagree $(\mathrm{SD})=1$ were used. The instrument is divided into two sections, A and B. Section A sought the personal information of the students which included sex, name of school and others. Section B was made up of 20 items which sought information relating to the self confidence, effort and perception in class work of the students on chemistry concept. The CAT is 25 objective questions with multiple choice items developed by the researchers based on the chemistry concepts (Chemical combination, electrovalent, covalent, co-ordinate covalent, metallic bond and intermolecular forces) that were taught to students. The questions were selected from past West African Senior School Certificate Examination (WASSCE) 
question between 1990 - 2013. The Chemistry Achievement Test (CAT) was used as pretest and posttest. The validity of the CAT and CSCS was ascertained by using experts' opinion. One expert in Education Department all from Nnamdi Azikiwe University, Awka. The reliability of CAT was established by administering the objective test items to 20 chemistry students randomly selected from community secondary school Obosi, which was in another area different from the sample area. The scores were calculated and Kudder Richerdson formular $(\mathrm{KR}-20)$ was used to determine the internal consistency of the items. The result of the analysis indicated reliability coefficient value of 0.87 . The KR -20 was used because the items are dichotomously scored (pass/fail). The same area and pollution was used to test the reliability of CSCS. The students' responses were scored and Cronbach alpha technique was used to ascertain the reliability with coefficient of 0.81 . Mean and standard deviation were used to answer research questions while hypotheses were tested at 0.05 level of significance using Analysis of Convenience (ANCOVA) for equivalence since the two groups are non equivalent.

\section{Results}

Research Question 1: What are the mean differences in the pretest and posttest self concept score of students taught with GLM instructional strategy in chemistry and those taught with lecture method?

Table 1: Difference in the Means and Standard Deviations of Pretest and Posttest Self Concept Scores of Students in the Experimental and Control Groups

Pretest Achievement Posttest Achievement

\begin{tabular}{lccccrl}
\hline Group & $\mathrm{N}$ & Mean & SD & Mean & SD & Mean difference \\
\hline Experimental & 50 & 30.80 & 12.39 & 51.44 & 15.20 & 20.64
\end{tabular}

$\begin{array}{lllllll}\text { Control } & 48 & 33.56 & 13.70 & 33.12 & 13.60 & 0.43\end{array}$

The data on Table 1 show that the students taught with GLM (experimental group) had a mean self concept score of 51.44 in their posttest and a standard deviation of 15.21. While those taught with conventional method (control group) had a mean posttest achievement score of 33.56 with standard deviation of 13.60. The result indicated that experimental group had a mean difference of 20.64 while control group had a mean difference of 0.43 . The various mean differences indicated that the experimental group had higher mean difference than the control group .This implies that the academic self concept of experimental group (GLM) improved more than control group (conventional method).

Research Question 2: What are the mean differences in the pretest and posttest mean achievement scores of students exposed to GLM in chemistry and those taught with conventional method? 
Table 2: Difference in Mean and standard Deviations of Pretest and Posttest Achievement Scores of Students in experimental and Control Groups

\begin{tabular}{lcccccc}
\hline & \multicolumn{3}{c}{ Pretest Achievement } & \multicolumn{3}{c}{ Posttest Achievement } \\
Group & $\mathrm{N}$ & Mean & SD & Mean & SD & Mean difference \\
\hline Experimental & 50 & 21.00 & 7.51 & 36.04 & 6.72 & 15.04 \\
Control & 48 & 22.13 & 7.74 & 22.63 & 7.38 & 0.50 \\
\hline
\end{tabular}

Table 2 shows that students taught with GLM (experimental group) have a mean posttest achievement score of 36.04 with standard deviation of 6.72. While the control group has a mean posttest achievement score of 22.26 with standard deviation of 7.38. It is observed from the table that difference in mean achievement score of the experimental group (15.04) is higher than the difference in mean achievement score of the control group (0.50). As such GLM enhance achievement more than conventional method in chemistry.

Research Question 3: What are the mean differences in the pretest and posttest mean achievement score of male and female students exposed to GLM instructional strategy?

Table 3: Difference in Mean and Standard Deviations of Pretest and Posttest Achievement Scores of Male and Female Students in experimental Group

\begin{tabular}{lcccccc}
\hline & \multicolumn{3}{c}{ Pretest Achievement } & \multicolumn{2}{c}{ Posttest Achievement } \\
Gender & $\mathrm{N}$ & Mean & SD & Mean & SD & Mean difference \\
\hline Male & 32 & 22.37 & 8.21 & 35.81 & 7.32 & 13.44 \\
Female & 18 & 18.56 & 5.47 & 36.44 & 5.67 & 17.88 \\
\hline
\end{tabular}

In Table 3 the male students have a mean achievement score of 35.81 with standard deviation of 7.32 in their posttest, while the female students have a mean achievement score of 36.04 with SD of 5.67 in their posttest. It was also observed that the mean difference of female students (17.88) is higher than the mean difference of male students (13.44). This implies that GLM improves female students' achievement in chemistry.

Research Question 4: What are the differences in the pretest and posttest mean self concept score of male and female students exposed to GLM in chemistry?

Table 4: Difference in Means and Standard Deviations of pretest and Posttest Self Concept Score of Male and Female Students in Experimental Group

\begin{tabular}{lcccccc}
\hline & \multicolumn{5}{c}{ Pretest Achievement } & \multicolumn{2}{c}{ Posttest Achievement } \\
Gender & $\mathrm{N}$ & Mean & SD & Mean & SD & Mean difference \\
\hline Male & 32 & 32.50 & 14.21 & 52.00 & 15.72 & 19.50 \\
Female & 18 & 27.78 & 7.72 & 50.44 & 15.15 & 22.70 \\
\hline
\end{tabular}


The result in table 5 shows that the posttest means self concept score of male students is 52.00 with the standard deviation of 19.50 . While the posttest means self concept score of female students is 50.44. The male mean difference (19.50) is less than the mean difference of the female students (22.66). This implies that female students' academic self concept is influenced and improved by GLM instructional strategy in chemistry learning.

Testing of hypotheses1: There are no significant differences in the mean achievement scores of students taught chemistry with GLM instructional strategy and those taught with conventional method.

Table 5: Analysis of Covariance (ANCOVA) of Chemistry Students' Mean Achievement Scores by Teaching Method and Gender

chemistry achievement posttest

\begin{tabular}{|c|c|c|c|c|c|c|}
\hline $\begin{array}{l}\text { Source } \\
\text { of variation }\end{array}$ & $\begin{array}{l}\text { Type III Sum } \\
\text { of Squares }\end{array}$ & $\mathrm{df}$ & $\begin{array}{l}\text { Mean } \\
\text { Square }\end{array}$ & $\mathrm{F}$ & Sig. & \\
\hline Corrected mode & 7349.396 & & 4 & 1837.349 & 93.220 & .000 \\
\hline Intercept & 1987.796 & 1 & 1987.796 & 100.853 & .000 & \\
\hline Precat & 2792.158 & 1 & 2792.158 & 141.663 & .000 & \\
\hline Group & 4566.349 & 1 & 4566.349 & 231.679 & .000 & \\
\hline Gender & 42.500 & 1 & 42.500 & 2.156 & .145 & \\
\hline Group* gender & 78.946 & 1 & 78.946 & 4.005 & .048 & \\
\hline Error & 1833.012 & 93 & 19.710 & & & \\
\hline Total & 94290.000 & 98 & & & & \\
\hline Corrected Total & 9182.408 & 97 & & & & \\
\hline
\end{tabular}

a. $\quad$ R Squared $=.800$ (Adjusted R Squared $=.792$ )

The result in Table 5 indicates a significant mean effect of method with respect to achievement in chemistry, since the probability of obtaining F- value (231.679) is 0.00 , which is less than the 0.05 level of significance that is $\mathrm{P}=0.00<0.05$. The null hypothesis therefore is not accepted, which means that there is a significant difference between the scores of students' taught chemistry with GLM instructional strategy and those taught with conventional method in favour of the formal.

Hypothesis 2: There is no significant difference in the mean self concept scores of students exposed to GLM in chemistry and those taught with expository method. 
Journal DOI: www.doi.org/10.46654/IJRESD

Article DOI: www.doi.org/10.46654/IJRESD.1401

Table 6: Analysis of Covariance (ANCOVA) of Students' Mean Self Concept Scores by Teaching Method and Gender

Tests of Between-Subjects Effects

Dependent Variable: self concept posttest

\begin{tabular}{|c|c|c|c|c|c|c|}
\hline $\begin{array}{l}\text { Source } \\
\text { of variation }\end{array}$ & $\begin{array}{l}\text { type III Sum } \\
\text { of Squares }\end{array}$ & df & $\begin{array}{l}\text { Mean } \\
\text { Square }\end{array}$ & $\mathrm{F}$ & Sig. & \\
\hline Corrected model & $22872 . \mathrm{eSS}^{3}$ & & 4 & 5718.160 & 98.887 & .000 \\
\hline Intercept & 1984.120 & 1 & 1984.120 & 34.312 & .000 & \\
\hline Prese & 14608.126 & 1 & 14608.126 & 252.624 & .000 & \\
\hline Group & 8960.683 & 1 & 8960.683 & 154.961 & .000 & \\
\hline Gender & 122.633 & 1 & 122.633 & 2.121 & .149 & \\
\hline Group* gender & 4.966 & 1 & 4.966 & .086 & .770 & \\
\hline Error & 5377.769 & 93 & 57.825 & & & \\
\hline Total & 205008.000 & 98 & & & & \\
\hline Corrected Total & 28250.408 & 97 & & & & \\
\hline
\end{tabular}

a. $\quad$ R Squared $=.810($ Adjusted R Squared $=.801)$

Table 6 indicates that the probability of obtaining the F- value (154.961) is 0.00 , which is less than the 0.05 level of significance $(\mathrm{P}=0.00<0.05)$. The null hypothesis therefore is not accepted, which means that there is significant difference between the mean self concepts score of students taught chemistry with GLM and those taught with conventional in favour of the GLM group.

Hypothesis 3: There is no significant difference in the mean achievement scores of male and female students exposed to GLM instructional strategy in chemistry

Table 5 shows that the probability of obtaining the F- value of 2.156 is 0.145 , which is higher than the 0.05 level of significant $(\mathrm{P}=0.145>0.05)$. The null hypothesis therefore is accepted, which means there is no significance difference between the mean achievement score of male and female students taught chemistry using GLM.

Hypothesis 4: There is no significant difference in the mean academic self concept scores of male and female students taught chemistry using GLM instructional strategy.

Table 6 shows that the probability of obtaining the F- value 2.121 is 0.149 which is higher than the 0.05 level of significance $(\mathrm{P}=0.149<0.05)$, therefore the null hypothesis is not rejected which means there is no significant difference between the mean achievement score of male and female students exposed to GLM instructional strategy.

Hypothesis 5: There is no significant interaction effect of method and gender on mean achievement scores of students in chemistry 


\section{Discussion}

The finding of this study show that students taught chemistry using generative learning model performs better than students taught using conventional method. The result indicates a significant difference between the mean achievement score of experimental group (generative learning model) and control group (conventional method) in preference of the experimental group with high mean score. This appears to be consistent with the findings of Ofiiah and Igbokwe (2010) that students taught conceptual change using GLM performs better than those taught with conventional method in Onitsha education zone. In addition, Ogunleye and Babajide (2011) findings confirm the results of the present study. They find that GLM instructional strategy increases students' achievement in chemistry more than that conventional method

The possible explanation of the significant difference can be that GLM phases serves as a guard which the teacher follows to direct instruction to the students. The experimental group is able to undergo learning following the five phases of GLM which allow the students to make connection between their previous knowledge and the chemistry concept to be learned. Also the phases may had helped them to explore ideas among themselves, ask question and formulate scientific explanation in chemistry concept that are otherwise impossible for them before.

In the area of impact of generative learning model on students' academic self concept in chemistry, the findings of this study show that students taught chemistry using GLM instructional strategy had higher mean self concept score than students taught using conventional method. There is a significant difference between the mean self concept scores of experimental group (GLM) and control group (conventional method) in preference of experimental group with higher mean self concept score. This finding is in line with the finding of, Abungu, Wachanga and Okonkwo (2012), who were of the view that constructivist instructional strategy stimulates students' academic self concept to learn thereby achievement more than students taught conventional method.

The high self concept shown by the experimental group may have been the impact of the exploration and elaboration phases of the generative learning model. These phases are interesting on its own, in the sense that, this phase encourages individual student to explore ideas and apply what they have learnt. Due to these phases students effort, confidence and self concept which are a component of student academic self concept towards studying of chemistry may have been stimulated and sustained.

In influence of gender on academic achievement in chemistry, the findings of this study revealed that mean achievement scores of male and female students taught chemistry using generative learning model were not at the same achievement level. Female students have a high mean achievement score than male. Also the finding indicated that gender did not influence students' achievement in chemistry significantly. This finding was in agreement with the findings of Akuezilo (2009) and Chukwu (2013) that there was no significant difference in academic achievement of students in chemistry due to gender.

Contrary to the present finding was the report of Wilkins (2014) that male students performed better than female in chemistry while Offiah and Igboegwu (2010) study revealed a significant gender difference on students' achievement in preference of male. The present study shows no significant gender difference, may be because it promotes much cooperation on the students. 
Also influence of gender on students' academic self concept in chemistry the findings of this study reveal that male and female students taught chemistry with generative learning model instructional strategy have almost equal mean self concept scores. The findings show that there is no significant difference due to gender on chemistry students' means self concept scores. These findings are in agreement with the finding of Okonkwo (2012) that no significant difference exist between mean self concept score of male and female students using science process skill teaching strategy. Oloyede (2010) also find that gender is not a significant factor in students' over all self efficacies in chemistry using metacognitive self assessments strategy. These finding agree with the findings of the present study

\section{Conclusion}

From the findings above, the following conclusions were made.

This study has provided empirical data as it concerns the impact of (GLM) in teaching and learning of chemistry. The generative learning model (GLM) instructional strategy has significant impact on students' academic self concept and achievement in chemistry. The experimental group taught chemistry with GLM has higher mean achievement and mean self concept score than the control group taught with conventional method.

There is influence of gender on the students' academic achievement in favour of female students, but gender did not influence students self concept in chemistry. This research is very important because it has established that GLM improved students' academic self concept which had improved their academic achievement. Also the academic self concept and achievement of male and female in experimental group are not significantly difference, which implies are gender unbiased.

\section{Recommendations}

Based on the findings of this study, the following recommendations were made:

1. Chemistry teachers should incorporate generative learning model as one of the instructional strategy used in teaching concepts in chemistry.

2. Counselors should organize orientation for Senior Secondary year one (SS1) students on science this will serve as a significant practical approach to explain to the students the importance of academic self concept in science learning.

3. The National Commission for Colleges of Education (NCCE) and Universities should ensure that in their teacher education programmes more emphases are laid on the usage of constructivist or innovative instructional strategy so that students teacher can have a model (GLM of Bybee et tal, 1999) in teaching of science.

4. Ministers of Education, both state and federal should sponsor teacher to attend Post graduate programmes. This is to make them improve and expose to innovative pedagogical science knowledge like (GLM) phases for effective teaching of science.

5. Generative Learning Model instructional strategy should also be used by chemistry teachers to enhance gender equity in academic achievement and academic self concept of all students in science.

6. The government should utilize the service of various bodies like science Teachers Association of Nigeria (STAN) and Chemical Society of Nigeria (CSN) and other to 
organize seminars, workshop and conferences to inform and train chemistry teacher and other science teachers on the use of GLM in teaching and learning. This will make them to update their knowledge.

7. Curriculum planner should include GLM as a model so that new teacher coming into teaching field will have a model of instruction to follow in guiding and directing instruction.

8. Researcher should go to schools and train science teachers on some constructivist instructional strategies like GLM as their research work. This is to make teachers learn how to use various phase of Bybee et al (1999) model for effective teaching and learning in learning environment or setting.

9. GLM should be used to teach female students in unity schools and other government secondary schools. 


\section{REFERENCES}

Akuezuilo, E.O. (2009). Effectiveness of prior knowledge of behavioural objectives and study questions on female students, mathematics achievement. Journal of STM Education I (1) 1 - 6.

Bauer, F.C. (2005).Beyond students Attitudes chemistry self concept inventory for assessment of the effective compound of students learning. Journal Of Chemical Education. 82 (12), 84 -89.

Bybee , R. W., Buchwald, C. E., Crissman S., Heil D.R., Kuerbisp.J., Matsumaoto C., \&Mclnerney, J. D. (1999).Science and technology education for the middle years: Framework for curriculum and instruction. Washington, DC: The Network.

Chukwu, L. (Ed). (2013). Basic Education in Nigeria concept and evaluation. reforms and innovation in Nigeria education, West and Solomon. coy.Ltd.

Grabowski, B. (2002). Generative learning contributions to the design of instruction and learning. Retrieved on 16 June 2015 from http://www.researchgate.publication 1267839866.

Ifeakor, A. C. (2006). Effect of Peer Assessment on Students' Academic Achievement in Chemistry in Nigeria secondary school 50th Annual proceedings of STAN 173-177.

Joyce B.Y.T., \& Shirley M. Y. (2007). A research analysis of the Academic self concept questionnaire. International Education Journal 8(2).470-484 .Retrieve from hppt://iej.com.au.

Majere, R. M. (2013). Self concept, perception of usefulness of physics and chemistry According to Type and Location of schools. Mier Journal of Education studies \& Practice. 3 (2) 318 - 323.

Marsh, H. H. (2005). Big fish little pond effect on Academic self-concept: cross cultural and cross- Disciplinary Generalization ability Annual conference of the Australian Association for research in Education, Sydney, http://www.aare.edu.au/05p/mar05389.

Marsh, H.W. (1990). The structure of academic self-concept: The march/shavelson model, Journal of educational psychology, 82 (4) 623-636. Dx.dox.org/10. 103

Neco, (2014). Chief Examiner's Report (Nigeria). May June, Examination logos Academic press ltd.

Nzewi, U. M. (2011).The science Teacher! Pivot for the realization of the 20:2020 National Agenda, Journal of science Education 11(1) 10 - 20.

Offiah, F.C. \&Igboegwu, E.W. (2010) Generative Teaching/Learning model: An effective method in teaching difficult concepts in chemistry. Africa Journal of Studies in Education 6 (1)35-38.

Ogundele, B. O \& Babajide, V.F.T. (2011). Generative instructional strategy enhances senior secondary school students achievement in physics. European journal of education studies. 3(3),201-207

Ojokuku, G. O. (2010). Understanding Chemistry for senior secondary school. Press.onchembooks.

Okonkwo C.O. (2012).Attribution style and academic self concept as correlations of students' academic achievements in chemistry. Unpublished $\mathrm{PhD}$ dissertation NnamdiAzikiwe University Awka.

Oloyede, O. I. (2010). Enhanced Mastery Learning Strategy on achievement and self concept in Senior Secondary School Chemistry. Humanities and social science Journal, 5 (1)19-24. 
Opara I.M. (2012). Self concept and gender as determinate of music achievement in junior secondary schools. Journal of the Nigeria Educational psychologist 6(1)166 - 169.

Sara, E. Neielsen I. \& Ellen (2015).Exploring the structure and function of the chemistry self concept inventory with high school chemistry students. Journal of chemical Education 92 (7) 1149-1158

Liu, W.C \& Wang, C.K.J (2005). Academic self concept: A cross sectional study of grade and gender difference in a Singapore secondary school. Asia pacific education review. 6(1)20-27

Taylor, M. (1994). Gender and power in counseling. British Journal of Guidance and Counseling, 22(3), 319 - 326.

Trautwein, Ulrich, Herbent, W. Nagu, \& Gabriel (2009). Within-school social comparison: How students perceive to standing of their class predicts academic self concept" Journal of Education Psychology 10(4) 853 - 866. doi: 10-37/a0016306.

W.A.E.C 2009-2013 chief Examiner's Report Nigeria SSCE May June Examination Lagos Academic press ltd.

Wilkins, J.L. (2014). Mathematics and science self concept in international investigation. The journal of experimental education, 72(4) 331 - 346.

Wittrock,M.C. (1999). Generative learning processes of the brain. Educational psychologist, 27 (4), 531-541. 